\title{
URBAN COMPACTNESS DI WILAYAH PERKOTAAN KENDAL
}

\section{URBAN COMPACTNESS IN KENDAL URBAN AREA}

\author{
Indra Altarans', Wisnu Pradoto ${ }^{2}$ \\ ${ }^{1}$ Magister Pembangunan Wilayah dan Kota, Universitas Diponegoro, Semarang; altaransaltarans@gmail.com \\ 2Departemen Perencanaan Wilayah dan Kota, Universitas Diponegoro, Semarang; wisnu.pradoto@gmail.com
}

\section{Info Artikel:}

- Artikel Masuk: 27/05/2018

\begin{abstract}
ABSTRAK
Urbanisasi merupakan proses terjadinya pengkotaan suatu desa sehingga menyebabkan rencana pembangunan kota menjadi tidak terkendali sehingga menimbulkan Urban Sprawl. Urbanisasi akan di proyeksikan beberapa tahun mendatang akan terjadi di Kabupaten Kendal, dikarenakan Pengembangan Kawasan Industri Jababeka di Kendal dalam skala yakni pada area seluas 2200 hektar. Tentu akan membawa dampak yang cukup signifikan, keberadaan lahan pertanian akan terancam akibat meningkatnya permintaan lahan. Upaya untuk membatasi Urban Sprawl di perkotaan kendal dapat dilakukan dengan konsep Compact City sebagai model pengembangan kota yang efisien. Dari itu, di perlukannya Urban Compactness untuk menimalisir Urban Sprawl di Perkotaan Kendal. Penelitian ini bertujuan untuk mengukur tingkat kekompakan kota di Wilayah Perkotaan Kendal, sehingga di perlukannya derajat pengukuran kota kompak yang disebut dengan Urban Compactness. Pengukuran Urban Compactness berdasarkan keseluruhan indikator Compact City antara lain, indikator Urban Compactness yang digunakan meliputi kepadatan, percampuran fungsi, aksesbilitas kota, dan kerterkaitan jaringan jalan dan transportasi. Penelitian ini menggunakan pendekatan kuantitatif yang dipakai dalam mengidentifikasi Urban Compactness di Wilayah Perkotaan Kendal, dengan teknik analisis yang digunakan untuk menjawab tujuan dan sasaran. Dalam penelitian ini menggunakan analisis deskriptif kuantitatif, analisis spasial, dan analisis scoring.

Hasil penelitian ini menunjukkan bahwa Urban Compactness di Wilayah Perkotaan Kendal, mengenai setiap indikator Compact City dalam penentuan Urban Compactness menunjukkan bahwa, pada tingkat Urban Compactness tertinggi berada di Kecamatan Kendal, sedangkan tingkat Urban Compactness sedang berada di Kecamatan Pegandon, dan tingkat Urban Compactness terendah terdapat di Kecamatan Brangsong, Kecamatan kaliwungu, Kecamatan Ngampel, dan Kecamatan Patebon.

Kata Kunci : Urban Sprawl, pembangunan berkelanjutan, Compact City,Urban Compactness, Perkotaan Kendal
\end{abstract}

\section{ABSTRACT}

Urbanization is the process of the occurrence of urban village so as to cause the city's development plan becomes uncontrolled causing Urban Sprawl. Urbanization will be projected in the next few years will occur in Kendal Regency, due to the development of Jababeka Industrial Estate in Kendal on a scale that is on an area of 2200 hectares. Of course will bring significant impact, the existence of agricultural land will be threatened due to increased demand for land. Efforts to limit Urban Sprawl in urban kendal can be done with the concept of Compact City as an efficient urban development model. Therefore, Urban Compactness is needed to minimize Urban Sprawl in Kendal Urban. This study aims to measure the degree of cohesiveness of cities in Kendal Urban Areas, so in need of a compact city size measurement called the Urban Compactness. Urban Compactness measurement based on the overall Compact City indicator, among others, Urban Compactness indicator that used include density, mixing function, city accessibility, and road network and transportation network. This study uses a quantitative approach used in identifying Urban Compactness in Kendal Urban Areas, with analytical techniques used to answer objectives and targets. In this study using quantitative descriptive analysis, spatial analysis, and scoring analysis. The results of this study indicate that Urban Compactness in Kendal Urban Area, about each Compact City indicator in Urban Compactness determination shows that, at the highest level of Urban Compactness is in District Kendal, while the level of Urban Compactness is in Pegandon Subdistrict, and the lowest level of Urban Compactness in District Brangsong, District Kaliwungu, District Ngampel, and District Patebon.

Keywords: Urban Sprawl, sustainable development, the Compact City, Urban Urban Compactness, Kendal

Copyright $\odot 2018$ JPWK-UNDIP This open access article is distributed under a Creative Commons Attribution (CC-BY-NC-SA) 4.0 International license

Cara men-sitasi:

Altarans, Indra., \& Pradoto, Wisnu. (2018). Urban Compactness di Wilayah Perkotaan Kendal. Jurnal Pembangunan Wilayah dan Kota, Vol 14, (4), 281-293 


\section{PENDAHULUAN}

Kawasan perkotaan memiliki daya tarik yang kuat bagi penduduk untuk datang dan mencari peradaban dengan tersedianya segala bentuk kebutuhan hidup. Dampaknya kota akan semakin berkembang seiring dengan pertambahan penduduk dari kawasan suburban maupun rural ke kota untuk mencari pekerjaan, tujuan pendidikan maupun bertempat tinggal. Fenomena seperti ini sering disebut dengan urbanisasi, menurut Harjoko dalam (Harahap, 2013) urbanisasi diartikan sebagai suatu proses perubahan dari wilayah Non-Urban menjadi Urban dan menyebabkan pemanfaatan ruang menjadi kurang proporsional. Selain itu Nas dalam (Harahap, 2013) mengemukakan bahwa urbanisasi dianggap sebagai suatu proses pembentukan kota yang digerakkan oleh perubahan struktural dalam masyarakat sehingga daerah-daerah yang dulu merupakan pedesaan dengan mata pencaharian sebagai petani, lambat laun memperoleh sifat kehidupan kota. Urbanisasi dinilai wajar sebagai upaya meningkatkan kesejahteraan kehidupan, namun arus urbanisasi yang tidak terkendali merusak strategi rencana pembangunan kota yang berkaitan dengan pemanfaatan ruang, sehingga terjadi pergeseran fungsi-fungsi kekotaan ke daerah pinggiran atau disebut dengan urban sprawl. Urban sprawl mengakibatkan terjadinya konversi lahan pertanian ke non pertanian hingga terjadinya proses densifikasi di pinggiran kota (Khaerunnisa, 2016). Beberapa tahun mendatang urbanisasi besar - besaran di proyeksikan akan terjadi di Kabupaten Kendal Provinsi Jawa Tengah, dikarenakan pengembangan Kawasan Industri Jababeka di Kabupaten Kendal dalam skala yang cukup besar, yakni pada area seluas 2200 hektar. Tentu akan membawa dampak yang cukup signifikan, selain perubahan struktur ruang dan struktur sosial ekonomi, keberadaan lahan pertanian akan terancam akibat meningkatnya permintaan lahan. Pengembangan Kawasan Industri aktivitas industri skala besar akan membangkitkan perkembangan permukiman yang cukup massif, perkembangan permukiman akan menuntut penyediaan infrastruktur dan kebutuhan energi akan meningkat. Pada gilirannya, peningkatan kebutuhan energi yang dipicu oleh aktivitas industri, permukiman dan transportasi akan menimbulkan emisi yang mengganggu kualitas lingkungan hidup. Jelas disini bahwa dampak pembangunan aktivitas industri perlu diantisipasi agar keseimbangan lingkungan tetap terjaga dan lahan pertanian tidak terganggu.

Upaya untuk membatasi Urban Sprawl dapat dilakukan dengan konsep pembangunan berkelanjutan (sustainable development). Terdapat tujuh pendekatan dalam menentukan bentuk kota yang paling berkelanjutan dan telah menghasilkan konsep Compact City sebagai model pengembangan kota yang efisien dalam pemanfaatan ruang (Kusumantoro, 2007). Konsep Compact City selayaknya konsep-konsep pengembangan kota saat ini yang merupakan sebuah visi dalam mewujudkan kota ke depannya dengan menggunakan kriteria tertentu. Tentu saja sebuah konsep tidak akan secara serta-merta diaplikasikan secara sempurna pada setiap kota, maka dari itu kemudian muncul metode untuk mengukur seberapa besar tingkat ketercapaian suatu kota sesuai dengan kriteria-kriteria tersebut. Terkait uraian tersebut diatas, maka penelitian ini dimaksudkan untuk mengukur tingkat Urban Compactness sebagai pengendalian pemanfaatan ruang untuk mengurangi dampak urbanisasi terkait Urban Sprawl di 6 Kecamatan di Wilayah Perkotaan Kendal antara lain Kecamatan Kendal, Brangsong, kaliwungu, Pegandon, Patebon, dan Ngampel.

\section{DATA DAN METODE}

Data serta informasi yang dibutuhkan berdasarkan analisis yang dilakukan pada penelitian ini berasal dari data primer serta data sekunder. Sedangkan Variabel yang digunakan sebagai karakteristik dalam pengukuran Compact City antara lain yang telah dirumuskan, yaitu (1) kepadatan (2) percampuran fungsi (3) aksesibiltas kota (4) keterkaitan jaringan jalan dan transportasi. Berikut mengenai kebutuhan data yang diperlukan dalam penelitian ini, akan dirangkum dalam Tabel 1. 
Tabel 1. Kebutuhan Data (Hasil Analisis, 2018)

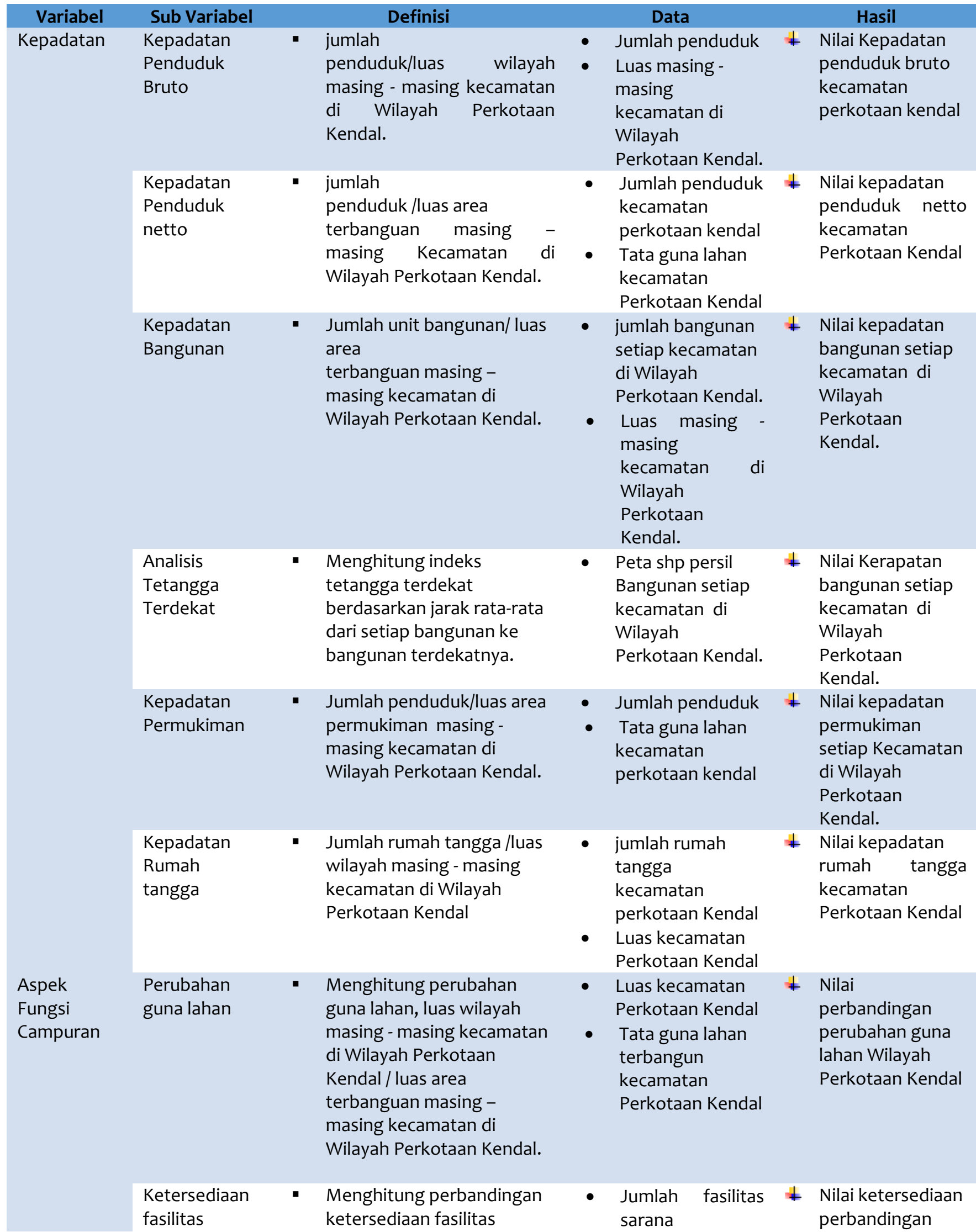




\begin{tabular}{|c|c|c|c|c|c|c|}
\hline Variabel & Sub Variabel & Definisi & & Data & & Hasil \\
\hline & & $\begin{array}{l}\text { Fasilitas eksiting/ } \\
\text { ketersediaan SNI }\end{array}$ & & $\begin{array}{l}\text { pendidikan, } \\
\text { kesehatan, dan } \\
\text { perdagangan dan } \\
\text { jasa }\end{array}$ & & $\begin{array}{l}\text { fasilitas sarana } \\
\text { pendidikan, } \\
\text { kesehatan, dan } \\
\text { perdagangan dan } \\
\text { jasa }\end{array}$ \\
\hline \multirow[t]{2}{*}{$\begin{array}{l}\text { Ukuran Dan } \\
\text { Akses Kota }\end{array}$} & $\begin{array}{l}\text { jarak } \\
\text { permukiman } \\
\text { terjauh ke } \\
\text { pusat } \\
\text { kecamatan }\end{array}$ & $\begin{array}{l}\text { Menghitung jarak } \\
\text { permukiman terjauh ke } \\
\text { pusat kecamatan di Wilayah } \\
\text { Perkotaan Kendal }\end{array}$ & • & Jaringan jalan & 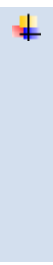 & $\begin{array}{l}\text { Nilai jarak } \\
\text { permukiman } \\
\text { terjauh ke pusat } \\
\text { kecamatan di } \\
\text { Wilayah } \\
\text { Perkotaan Kendal }\end{array}$ \\
\hline & $\begin{array}{l}\text { Jarak } \\
\text { permukiman } \\
\text { terjauh ke } \\
\text { Kota }\end{array}$ & $\begin{array}{l}\text { - Menghitung jarak } \\
\text { permukiman terjauh ke } \\
\text { pusat kota di Wilayah } \\
\text { Perkotaan Kendal }\end{array}$ & $\bullet$ & Jaringan jalan & 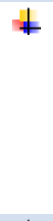 & $\begin{array}{l}\text { Nilai jarak } \\
\text { permukiman } \\
\text { terjauh ke pusat } \\
\text { kota di Wilayah } \\
\text { Perkotaan Kendal }\end{array}$ \\
\hline \multirow[t]{2}{*}{$\begin{array}{l}\text { Koneksivitas } \\
\text { dan } \\
\text { Transportasi }\end{array}$} & $\begin{array}{l}\text { Perbandingan } \\
\text { panjang rute } \\
\text { angkutan } \\
\text { umum dan } \\
\text { panjang jalan }\end{array}$ & $\begin{array}{l}\text { - Nilai perbandingan panjang } \\
\text { rute angkutan umum } \\
\text { dengan panjang jalan } \\
\text { kecamatan Perkotaan } \\
\text { Kendal }\end{array}$ & $\bullet$ & $\begin{array}{l}\text { Rute trayek } \\
\text { angkutan bus } \\
\text { umum Peta } \\
\text { jaringan jalan }\end{array}$ & $\sharp$ & $\begin{array}{l}\text { Nilai } \\
\text { perbandingan } \\
\text { panjang rute } \\
\text { angkutan umum } \\
\text { dengan panjang } \\
\text { jalan kecamatan } \\
\text { Perkotaan Kendal }\end{array}$ \\
\hline & $\begin{array}{l}\text { kepadatan } \\
\text { Jaringan } \\
\text { jalan }\end{array}$ & - Panjang jalan/luas wilayah & - & $\begin{array}{l}\text { Peta jaringan } \\
\text { jalan }\end{array}$ & 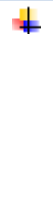 & $\begin{array}{l}\text { Nilai } \\
\text { PERBANDINGAN } \\
\text { panjang jalan } \\
\text { dengan } \\
\text { luas wilayah }\end{array}$ \\
\hline
\end{tabular}

Fokus penelitian Urban Compactness di Wilayah Perkotaan Kendal terbagi atas enam kecamatan, untuk lebih jelasnya mengenai lokasi penelitian, berikut Gambar 1. mengenai peta konstelasi fokus penelitian administrasi Perkotaan Kendal terhadap Kabupaten Kendal.
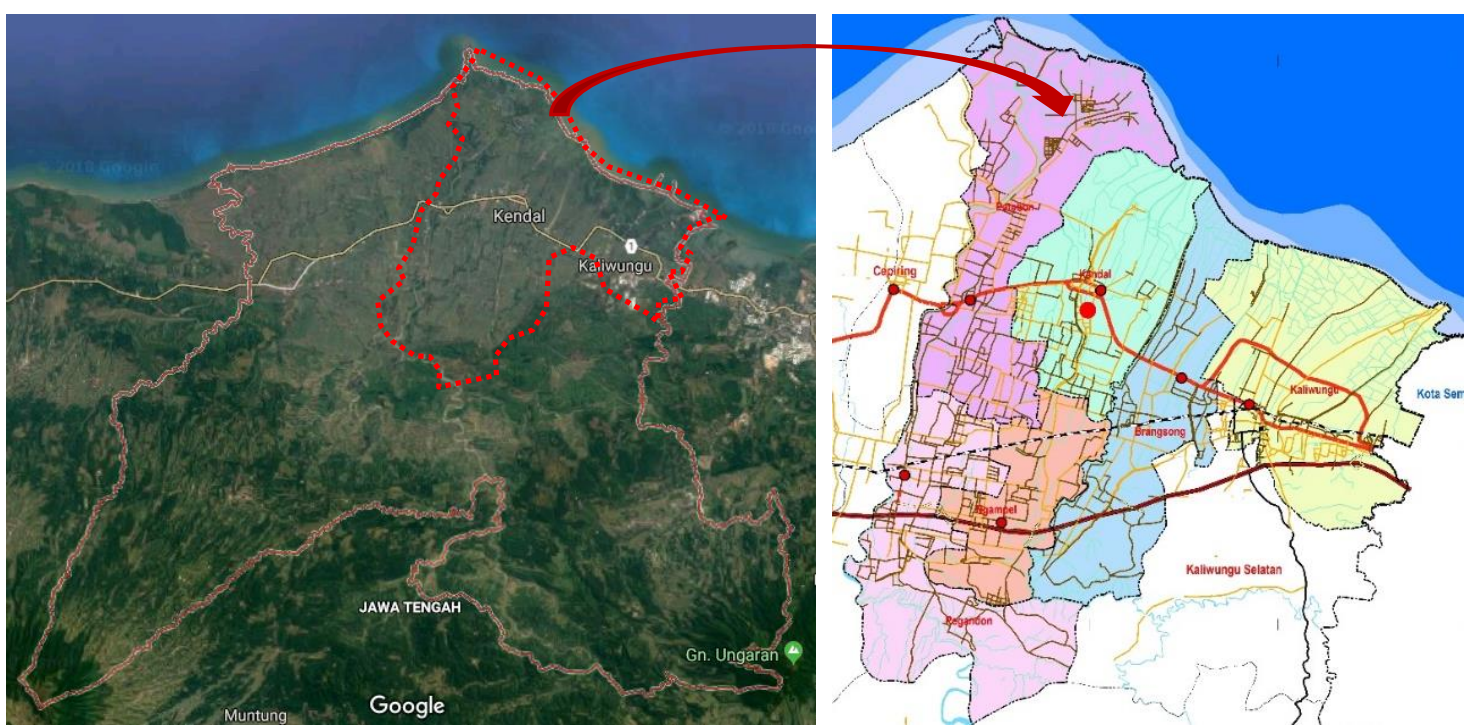

Gambar 1. Peta Fokus penelitian Urban Compactness di Wilayah Perkotaan Kendal (Hasi Analisis, 2018) 
Teknik analisis yang dipergunakan dalam penelitian ini adalah analisis penilaian atau skoring, analisis deskriptif dan analisis spasial. Analisis penilaian atau skoring dan deskriptif spasial menjelaskan data dan informasi yang di dapatkan melalui survei primer (observasi). Analisis deskriptif digunakan untuk menjelaskan hasil dari kompilasi data, analisis ini memberikan hasil dari spasial analisis yang disebut dengan deskriptif spasial, dan hasil dari perhitungan rumus yang disebut dengan deskriptif kuantitatif. Analisis spasial digunakan untuk menganalisis Urban Compactness Perkotaan Kendal antara lain Density Kernel, Network Analysis dan Nearest Neighbor dan hasil dari analisis ini akan di gambarkan dalam bentuk peta, sedangkan analisis Penilaian atau skoring digunakan untuk menggambarkan tingkat Urban Compactness Perkotaan Kendal. Proses identifikasi Tingkat Urban Compactness dilakukan dengan metode skoring terhadap setiap subvariabel Urban Compactness itu sendiri, data didapatkan dari nilai kepadatan, nilai subvariabel fungsi campuran, nilai subvariabel aksesibiltas kota dan nilai subvariabel keterkaitann jaringan jalan dan transportasi.

\section{HASIL DAN PEMBAHASAN}

\subsection{Analisis Kepadatan (density) di Wilayah Perkotaan Kendal}

Dimensi Kepadatan yaitu merupakan salah satu dimensi yang dilihat dalam tinjauan penilain kekompakan suatu kawasan pada Perkotaan, dimensi kepadatan dilihat dari kepadatan bruto, kepadatan netto, kepadatan permukiman, kepadatan bangunan, tetangga terdekat, dan kepadatan rumah tangga. Kepadatan menunjukan tingginya intensitas pemanfaatan lahan suatu kawasan dengan berbagai macam pemanfaatan lahan yang ada di suatu kawasan pada Perkotaan.

\subsubsection{Kepadatan Bruto Wilayah Perkotaan Kendal}

Analisis kepadatan bruto pada enam kecamatan yang berada di Wilayah Perkotaan dilakukan dengan menggunakan data jumlah penduduk tahun 2017 dibagi dengan luas Wilayah. Berikut adalah analisis kepadatan kepadatan bruto pada Tabel 2.

Tabel 2. Kepadatan Bruto (Jiwa/Ha) Setiap Kecamatan Di Wilayah Perkotaan Kendal Pada Tahun 2017 ( Hasil Analisis, 2018)

\begin{tabular}{|c|c|c|c|c|c|c|}
\hline No & Kecamatan & $\begin{array}{l}\text { Jumlah } \\
\text { Penduduk } \\
\text { (Jiwa) }\end{array}$ & $\begin{array}{l}\text { Luas } \\
\text { Wilayah } \\
\text { (Ha) }\end{array}$ & $\begin{array}{c}\text { Persentase } \\
\text { Luas } \\
\text { Wilayah (\%) }\end{array}$ & $\begin{array}{c}\text { Kepadatan } \\
\text { Bruto } \\
\text { (Jiwa/Ha) }\end{array}$ & $\begin{array}{c}\text { Persentase } \\
\text { Kepadatan } \\
\text { Bruto } \\
\text { (Jiwa/Ha) }\end{array}$ \\
\hline 1 & Kaliwungu & 58.734 & 4773 & 21 & 12,305 & 15 \\
\hline 2 & Brangsong & 47.538 & 3454 & 15 & 13,763 & 16 \\
\hline 3 & Pegandon & 36.906 & 3112 & 14 & 11,859 & 14 \\
\hline 4 & Ngampel & 35.708 & 3388 & 15 & 10,540 & 12 \\
\hline 5 & Patebon & 57.722 & 4430 & 20 & 13,030 & 16 \\
\hline \multirow[t]{2}{*}{6} & Kota Kendal & 55.547 & 2749 & 12 & 20,206 & 24 \\
\hline & Jumlah & 292.155 & 21906 & 100 & 81,704 & 100 \\
\hline
\end{tabular}

Berdasarkan analisis kepadatan bruto pada Tabel 2. dapat diketahui bahwa kepadatan bruto terendah adalah 10,540 jiwa/ha terdapat di Kecamatan Ngampel, sedangkan kepadatan bruto tertinggi adalah 20,206 jiwa/ha terdapat di Kcematan Kendal. Berdasarkan hasil tersebut didapat klasifikasi kepadatan bruto. Kecamatan dengan kepadatan bruto rendah mengindikasikan tingkat Compact City yang semakin rendah, sedangkan Kecamatan dengan kepadatan bruto tinggi mengindikasikan tingkat Compact City yang semakin tinggi. 


\subsubsection{Kepadatan netto di Wilayah Perkotaan Kendal}

Analisis kepadatan netto pada enam kecamatan yang berada di Wilayah Perkotaan dilakukan dengan menggunakan data jumlah penduduk tahun 2017 dibagi dengan luas lahan terbangun tahun 2013. Berikut adalah analisis kepadatan kepadatan netto pada tabel 3. Berdasarkan analisis kepadatan netto pada Tabel 3. dapat diketahui bahwa kepadatan netto terendah adalah 77,512 jiwa/ha terdapat di Kecamatan Pegandon, sedangkan kepadatan netto tertinggi adalah 100,998 jiwa/ha terdapat di kecamatan Ngampel. Berdasarkan hasil tersebut didapat klasifikasi kepadatan netto. Kecamatan dengan kepadatan netto rendah mengindikasikan tingkat Compact City yang semakin rendah, sedangkan Kecamatan dengan kepadatan netto tinggi mengindikasikan tingkat Compact City yang semakin tinggi.

Tabel 3. Kepadatan Netto (Jiwa/Ha) Setiap Kecamatan Di Wilayah Perkotaan Kendal Pada Tahun 2017 ( Hasil Analisis,2018)

\begin{tabular}{|c|c|c|c|c|c|c|}
\hline No & Kecamatan & $\begin{array}{l}\text { Jumlah } \\
\text { Penduduk } \\
\text { (Jiwa) }\end{array}$ & $\begin{array}{l}\text { Luas Lahan } \\
\text { Terbangun } \\
\text { (Ha) }\end{array}$ & $\begin{array}{c}\text { Persentase } \\
\text { Luas Lahan } \\
\text { Terbangun } \\
\text { (\%) }\end{array}$ & $\begin{array}{c}\text { Kepadatan } \\
\text { Terbangun } \\
\text { (Jiwa/Ha) }\end{array}$ & $\begin{array}{c}\text { Persentase } \\
\text { Kepadatan } \\
\text { Terbangun } \\
\text { (\%) }\end{array}$ \\
\hline 1 & Kaliwungu & 58.734 & 651,06 & 20 & 90,213 & 17 \\
\hline 2 & Brangsong & 47.538 & 511,86 & 16 & 92,873 & 17 \\
\hline 3 & Pegandon & 36.906 & 476,13 & 14 & 77,512 & 14 \\
\hline 4 & Ngampel & 35.708 & 353,55 & 11 & 100,998 & 19 \\
\hline 5 & Patebon & 57.722 & 687,53 & 21 & 83,956 & 16 \\
\hline 6 & Kota Kendal & 55.547 & 620,65 & 19 & 89,498 & 17 \\
\hline & Jumlah & 292.155 & 3300,78 & 100 & 535,051 & 100 \\
\hline
\end{tabular}

\subsubsection{Kepadatan bangunan di Wilayah Perkotaan Kendal}

Analisis kepadatan bangunan pada enam kecamatan yang berada di Wilayah Perkotaan dilakukan dengan menggunakan data jumlah unit bangunan tahun 2017 dibagi dengan luas lahan terbangun tahun 2013. Berikut adalah analisis kepadatan bangunan pada Tabel 4.

Tabel 4. Kepadatan Bangunan (Unit/Ha) Setiap Kecamatan Di Wilayah Perkotaan Kendal Pada Tahun 2017 ( Hasil Analisis,2018)

\begin{tabular}{|ccccccc} 
No & $\begin{array}{c}\text { Kecamatan } \\
\text { Kecamatan } \\
\text { Di Wilayah } \\
\text { Perkotaan } \\
\text { Kendal }\end{array}$ & $\begin{array}{c}\text { Jumlah } \\
\text { Bangunan } \\
\text { (Unit) } \\
\text { Tahun 2017 }\end{array}$ & $\begin{array}{c}\text { Presentase } \\
\text { (\%) Jumlah } \\
\text { Bangunan } \\
\text { (Unit) } \\
\text { Tahun 2017 }\end{array}$ & $\begin{array}{c}\text { Luas Lahan } \\
\text { Terbangun } \\
\text { (Ha) Tahun } \\
\mathbf{2 0 1 3}\end{array}$ & $\begin{array}{c}\text { Persentase } \\
\text { (\%) Luas } \\
\text { Lahan } \\
\text { Terbangun }\end{array}$ & $\begin{array}{c}\text { Kepadatan } \\
\text { Bangunan } \\
\text { (Unit/Ha) }\end{array}$ \\
$\begin{array}{c}\text { Tahun 2017 } \\
1\end{array}$ & Kaliwungu & 11.340 & 14 & 651,06 & 20 & 17,418 \\
\hline 2 & Brangsong & 11.005 & 13 & 511,86 & 16 & 21,500 \\
\hline 3 & Pegandon & 13.456 & 16 & 476,13 & 14 & 28,261 \\
\hline 4 & Ngampel & 10.914 & 13 & 353,55 & 11 & 30,870 \\
\hline 5 & Patebon & 14.584 & 18 & 687,53 & 21 & 21,212 \\
\hline 6 & Kendal & 20.756 & 25 & 620,65 & 19 & 33,442 \\
\hline & jumlah & 82.055 & 100 & 3300,78 & 100 & 152,703 \\
\hline
\end{tabular}

Berdasarkan analisis kepadatan bangunan pada Tabel 4. dapat diketahui bahwa kepadatan bangunan terendah adalah 17,418 unit/ha terdapat di Kecamatan Kaliwungu, sedangkan kepadatan bangunan tertinggi adalah 33,442 unit/ha terdapat di Kecamatan Kendal. Berdasarkan hasil tersebut didapat klasifikasi kepadatan bangunan. Kecamatan dengan kepadatan bangunan rendah 
mengindikasikan tingkat Compact City yang semakin rendah, sedangkan Kecamatan dengan kepadatan bangunan tinggi mengindikasikan tingkat Compact City yang semakin tinggi.

\subsubsection{Kepadatan permukiman Wilayah Perkotaan Kendal}

Analisis kepadatan permukiman pada enam kecamatan yang berada di Wilayah Perkotaan dilakukan dengan menggunakan data jumlah penduduk tahun 2017 dibagi dengan luas lahan permukiman tahun 2013. Berikut adalah analisis kepadatan permukiman pada tabel 5. Berdasarkan analisis kepadatan bangunan pada Tabel 5. dapat diketahui bahwa kepadatan permukiman terendah adalah 80,04 jiwa/ha terdapat di Kecamatan Pegandon, sedangkan kepadatan permukiman tertinggi adalah 156,40 jiwa/ha terdapat di Kecamatan Kaliwungu. Berdasarkan hasil tersebut didapat klasifikasi kepadatan permukiman. Kecamatan dengan kepadatan permukiman rendah mengindikasikan tingkat Compact City yang semakin rendah, sedangkan Kecamatan dengan kepadatan permukiman tinggi mengindikasikan tingkat Compact City yang semakin tinggi.

Tabel 5. Kepadatan Permukiman (Jiwa/Ha) Setiap Kecamatan Di Wilayah Perkotaan Kendal Pada Tahun 2017 ( Hasil Analisis,2018)

\begin{tabular}{|c|c|c|c|c|c|c|}
\hline No & Kecamatan & $\begin{array}{l}\text { Jumlah } \\
\text { Penduduk } \\
\text { (Jiwa) }\end{array}$ & $\begin{array}{l}\text { Luas Lahan } \\
\text { Permukiman } \\
\text { (Ha) }\end{array}$ & $\begin{array}{c}\text { Presentase } \\
\text { Luas Lahan } \\
\text { Permukiman } \\
\text { (\%) }\end{array}$ & $\begin{array}{l}\text { Kepadatan } \\
\text { Permukiman } \\
\text { (Jiwa/Ha) }\end{array}$ & $\begin{array}{c}\text { Presentase } \\
\text { Kepadatan } \\
\text { Permukiman } \\
\text { (\%) }\end{array}$ \\
\hline 1 & Kaliwungu & 58.734 & 375,54 & 13 & 156,40 & 25 \\
\hline 2 & Brangsong & 47.538 & 464,97 & 16 & 102,24 & 16 \\
\hline 3 & Pegandon & 36.906 & 461,08 & 16 & 80,04 & 13 \\
\hline 4 & Ngampel & 35.708 & 337,88 & 12 & 105,68 & 17 \\
\hline 5 & Patebon & 57.722 & 657,57 & 23 & 87,78 & 14 \\
\hline \multirow[t]{2}{*}{6} & Kota Kendal & 55.547 & 524,73 & 19 & 105,86 & 17 \\
\hline & Jumlah & 292.155 & 2821,77 & 100 & 638,00 & 100 \\
\hline
\end{tabular}

\subsubsection{Kepadatan rumah tangga di Wilayah Perkotaan Kendal}

Analisis kepadatan rumah tangga pada enam kecamatan yang berada di Wilayah Perkotaan Kendal, dilakukan dengan menggunakan data jumlah rumah tangga tahun 2017 dibagi dengan luas wilayah. Berikut adalah analisis kepadatan rumah tangga pada Tabel 6.

Tabel 6. Kepadatan Rumah Tangga (RT/Ha) Setiap Kecamatan Di Wilayah Perkotaan Kendal Pada Tahun 2017 (Hasil Analisis,2018)

\begin{tabular}{|c|c|c|c|c|c|c|}
\hline No & Kecamatan & $\begin{array}{c}\text { Jumlah } \\
\text { Rumah } \\
\text { Tangga } \\
\text { (RT) }\end{array}$ & $\begin{array}{c}\text { Luas } \\
\text { Wilayah } \\
\text { Terbangun } \\
\text { (Ha) }\end{array}$ & $\begin{array}{l}\text { Persentase } \\
\text { Luas } \\
\text { Wilayah (\%) }\end{array}$ & $\begin{array}{c}\text { Kepadatan } \\
\text { Rumah } \\
\text { Tangga } \\
\text { (RT/Ha) }\end{array}$ & $\begin{array}{c}\text { Persentase } \\
\text { Kepadatan } \\
\text { Rumah } \\
\text { Tangga(\%) }\end{array}$ \\
\hline 1 & Kaliwungu & 17.426 & 2142,79 & 19,32 & 15.283 & 20,11 \\
\hline 2 & Brangsong & 14.990 & 1990,22 & 17,94 & 13.000 & 17,10 \\
\hline 3 & Pegandon & 14.750 & 1621,59 & 14,62 & 13.128 & 17,27 \\
\hline 4 & Ngampel & 12.098 & 352,58 & 3,18 & 11.745 & 15,45 \\
\hline 5 & Patebon & 14.750 & 2606,98 & 23,50 & 12.143 & 15,98 \\
\hline 6 & Kota Kendal & 13.084 & 2378,35 & 21,44 & 10.706 & 14,09 \\
\hline & Jumlah & 87.098 & $11.092,51$ & 100 & 76005 & 100 \\
\hline
\end{tabular}

Berdasarkan analisis kepadatan rumah tangga pada Tabel 6. dapat diketahui bahwa kepadatan rumah tangga terendah adalah $10.706 \mathrm{rt} / \mathrm{ha}$ terdapat di Kecamatan Kendal, sedangkan kepadatan rumah tangga tertinggi adalah $15.283 \mathrm{rt} / \mathrm{ha}$ terdapat di Kecamatan Kaliwungu. Berdasarkan hasil tersebut didapat 
klasifikasi kepadatan rumah tangga. Kecamatan dengan kepadatan rumah tangga rendah mengindikasikan tingkat Compact City yang semakin rendah, sedangkan Kecamatan dengan kepadatan rumah tangga tinggi mengindikasikan tingkat Compact City yang semakin tinggi.

\subsubsection{Analisis tetangga terdekat di Wilayah Perkotaan Kendal}

Analisis Tetangga Terdekat yaitu Menghitung indeks tetangga terdekat berdasarkan jarak rata-rata dari setiap bangunan ke bangunan terdekatnya, Indeks tetangga terdekat dinyatakan Jika indeks kurang dari 1, pola tersebut menunjukkan clustering atau mengelompok Jika indeks lebih besar dari 1, kecenderungannya menuju dispersi atau menyebar, rumus tetangga terdekat akan menghasilkan hasil antara o dan 2.15. Analisis tetangga terdekat pada enam kecamatan yang berada di Wilayah Perkotaan dilakukan dengan menggunakan data jumlah unit bangunan tahun 2017. Berikut adalah analisis tetangga terdekat pada Tabel 7. Berdasarkan analisis tetangga terdekat pada Tabel 7. dapat diketahui bahwa analisis tetangga terdekat terendah adalah 0,45 nearest neighbor ratio terdapat di Kecamatan Kendal dan Kecamatan Ngampel, sedangkan tetangga terdekat tertinggi adalah 0,34 nearest neighbor ratio terdapat di Kecamatan Kaliwungu. Berdasarkan hasil tersebut didapat klasifikasi tetangga terdekat. Kecamatan dengan tetangga terdekat rendah mengindikasikan tingkat Compact City yang semakin rendah, sedangkan Kecamatan dengan tetangga terdekat tinggi mengindikasikan tingkat Compact City yang semakin tinggi.

Tabel 7. Analisis Tetangga Terdekat Setiap Kecamatan Di Wilayah Perkotaan Kendal Pada Tahun 2017 ( Hasil Analisis,2018)

\begin{tabular}{|clccc|}
\hline No & $\begin{array}{c}\text { Kecamatan Kecamatan Di } \\
\text { Wilayah Perkotaan Kendal }\end{array}$ & $\begin{array}{c}\text { Jumlah Bangunan (Unit) } \\
\text { Tahun 2017 }\end{array}$ & $\begin{array}{c}\text { Luas } \\
\text { Wilayah (Ha) }\end{array}$ & $\begin{array}{c}\text { Nearest Neighbor } \\
\text { Ratio }\end{array}$ \\
\hline 1 & Kaliwungu & 11.340 & 4.773 & 0,34 \\
\hline 2 & Brangsong & 11.005 & 3.454 & 0,37 \\
\hline 3 & Kendal & 20.756 & 3.112 & 0,45 \\
\hline 4 & Patebon & 14.584 & 3.388 & 0,40 \\
\hline 5 & Pegandon & 13.456 & 4.430 & 0,41 \\
\hline 6 & Ngampel & 10.914 & 2.749 & 0,45 \\
\hline jumlah & $\quad 82.055$ & 21906 & 2,431 & \\
\hline
\end{tabular}

\subsection{Analisis Berdasarkan Aspek Fungsi Campuran Wilayah Perkotaan Kendal}

\subsubsection{Perubahan penggunaan lahan di Wilayah Perkotaan Kendal}

Analisis perubahan penggunaan lahan pada enam kecamatan yang berada di Wilayah Perkotaan Kendal, dilakukan dengan menggunakan data luas lahan terbangun tahun 2017 dibagi dengan luas wilayah. Berikut adalah analisis Perubahan penggunaan lahan pada Tabel 8.

Tabel 8. Perubahan Guna Lahan Terbangun Setiap Kecamatan Di Wilayah Perkotaan Kendal Pada Tahun 2017 (Hasil Analisis,2018)

\begin{tabular}{|llccc|} 
No & Kecamatan & $\begin{array}{c}\text { Luas Lahan } \\
\text { Terbangun }(\mathrm{Ha})\end{array}$ & $\begin{array}{c}\text { Luas Wilayah } \\
(\mathrm{Ha})\end{array}$ & $\begin{array}{c}\text { Rasio Perubahan } \\
\text { Guna Lahan }\end{array}$ \\
\hline 1 & Kaliwungu & 2142,79 & 4773 & 0,45 \\
\hline 2 & Brangsong & 1990,22 & 3454 & 0,58 \\
\hline 3 & Pegandon & 1621,59 & 3112 & 0,52 \\
\hline 4 & Ngampel & 1589,4 & 3388 & 0,47 \\
\hline 5 & Patebon & 2607,98 & 4430 & 0,59 \\
6 & Kota Kendal & 2378,35 & 2749 & 0,87 \\
\hline
\end{tabular}

Berdasarkan analisis rasio perubahan guna lahan pada Tabel 8. dapat diketahui bahwa rasio perubahan guna lahan terendah adalah 0,47 hektar terdapat di Kecamatan Ngampel, sedangkan rasio perubahan guna lahan tertinggi adalah 0,87 hektar terdapat di Kecamatan Kendal. Berdasarkan hasil 
tersebut didapat klasifikasi rasio perubahan guna lahan. Kecamatan dengan rasio perubahan guna lahan rendah mengindikasikan tingkat Compact City yang semakin rendah, sedangkan Kecamatan dengan rasio perubahan guna lahan tinggi mengindikasikan tingkat Compact City yang semakin tinggi.

\subsubsection{Ketersediaan fasilitas di Wilayah Perkotaan Kendal}

Analisis ketersediaan fasilitas pada enam kecamatan yang berada di Wilayah Perkotaan Kendal, dilakukan dengan menggunakan data jumlah eksisting fasilitas Pendidikan, kesehatan, dan Perdagangan dan jasa tahun 2017 dibagi dengan SNI ketersediaan sarana eksisting fasilitas Pendidikan, kesehatan, dan Perdagangan dan jasa tahun 2017. Berikut adalah analisis ketersediaan fasilitas pada Tabel 9. Berdasarkan analisis rasio ketersediaan sarana pendidikan, sarana kesehatan, sarana perdagangan dan jasa pada Tabel 9. dapat diketahui bahwa rasio ketersediaan sarana pendidikan, sarana kesehatan, sarana perdagangan dan jasa terendah adalah 13,4 terdapat di Kecamatan Ngampel, sedangkan rasio ketersediaan sarana pendidikan, sarana kesehatan, sarana perdagangan dan jasa tertinggi adalah 18,2 terdapat di Kecamatan Kendal. Berdasarkan hasil tersebut didapat klasifikasi rasio ketersediaan sarana pendidikan, sarana kesehatan, sarana perdagangan dan jasa. Kecamatan dengan rasio ketersediaan sarana pendidikan, sarana kesehatan, sarana perdagangan dan jasa rendah mengindikasikan tingkat Compact City yang semakin rendah, sedangkan Kecamatan dengan rasio ketersediaan sarana pendidikan, sarana kesehatan, sarana perdagangan dan jasa tinggi mengindikasikan tingkat Compact City yang semakin tinggi.

Tabel 9. Klasifikasi Ketersediaan Sarana Pendidikan, Sarana Kesehatan, Sarana Perdagangan Dan Jasa Setiap Kecamatan Di Wilayah Perkotaan Kendal Pada Tahun 2017 (Hasil Analisis,2018)

\begin{tabular}{|c|c|c|c|c|c|}
\hline No & $\begin{array}{c}\text { Nama } \\
\text { Kecamatan }\end{array}$ & $\begin{array}{c}\text { Sarana } \\
\text { Pendidikan }\end{array}$ & $\begin{array}{c}\text { Sarana } \\
\text { Kesehatan }\end{array}$ & $\begin{array}{c}\text { Sarana } \\
\text { Perdagangan } \\
\text { Dan Jasa }\end{array}$ & $\begin{array}{c}\text { Keseluruhan } \\
\text { Sarana }\end{array}$ \\
\hline 1 & Kaliwungu & 2,1 & 9,4 & 3 & 14,5 \\
\hline 2 & Brangsong & 2,6 & 4,2 & 7 & 13,8 \\
\hline 3 & Pegandon & 3,1 & 7 & 7 & 17,1 \\
\hline 4 & Ngampel & 2,5 & 5,9 & 5 & 13,4 \\
\hline 5 & Patebon & 2,9 & 10,3 & 5 & 18,2 \\
\hline 6 & Kendal & 3,4 & 6,4 & 6 & 15,8 \\
\hline
\end{tabular}

\subsection{Aksesibilitas kota di Wilayah Perkotaan Kendal}

\subsubsection{Analisis jarak pusat kecamatan ke batas pinggiran kecamatan di Wilayah Perkotaan Kendal}

Analisis jarak pusat kecamatan ke batas pinggiran kecamatan di Wilayah Perkotaan Kendal dilakukan dengan mengukur jarak terjauh dari bangunan pada kelurahan pada kecamatan tersebut ke pusat Kecamatannya di Wilayah Perkotaan Kendal. Analisis ini dilakukan dengan menggunakan bantuan Arc Gis melalui network analysis. Berikut adalah analisis Analisis jarak pusat kecamatan ke batas pinggiran kecamatan yang ditunjuukan pada Tabel 10.

Tabel 10. Jarak Bangunan Ke Pusat Kecamatan Di Wilayah Perkotaan Kendal Tahun 2017

(Hasil Analisis,2018)

\begin{tabular}{|llcc} 
No & Kecamatan & $\begin{array}{c}\text { Luas } \\
\text { Wilayah } \\
(\mathrm{Ha})\end{array}$ & $\begin{array}{c}\text { Jarak Bangunan Terjauh Ke } \\
\text { Pusat Kecamatan }(\mathrm{Km})\end{array}$ \\
\hline 1 & Kaliwungu & 4773 & 6,22 \\
\hline 2 & Brangsong & 3454 & 8,06 \\
\hline 3 & Pegandon & 3112 & 6,29 \\
\hline 4 & Ngampel & 3388 & 4,82 \\
\hline 5 & Patebon & 4430 & 8,52 \\
6 & Kota Kendal & 2749 & 3,41 \\
\hline
\end{tabular}


Berdasarkan analisis Jarak bangunan ke pusat Kecamatan pada Tabel 10. dapat diketahui bahwa Jarak bangunan terjauh ke pusat kecamatan adalah 8,52 km terdapat di Kecamatan Patebon, sedangkan Jarak bangunan terdekat ke pusat Kecamatan adalah 3,41 km terdapat di Kecamatan Kendal. Berdasarkan hasil tersebut didapat klasifikasi Jarak bangunan ke pusat Kecamatan. Kecamatan dengan Jarak bangunan terjauh ke pusat kecamatan mengindikasikan tingkat Compact City yang semakin rendah, sedangkan kecamatan dengan Jarak bangunan ke pusat Kecamatan terdekat mengindikasikan tingkat Compact City yang semakin tinggi.

\subsubsection{Analisis jarak ke pusat kota di Wilayah Perkotaan Kendal}

Analisis jarak ke pusat kota dilakukan dengan mengukur jarak terjauh dari bangunan pada kelurahan di Kecamatan di Wilayah Perkotaan Kendal Ke pusat Kota Kendal. Analisis ini dilakukan dengan menggunakan bantuan Arc Gis melalui network analysis. Berikut adalah analisis jarak ke pusat kota yang ditunjuukan pada Tabel 11Berdasarkan analisis Jarak bangunan ke pusat Kecamatan pada Tabel 11 dapat diketahui bahwa Jarak bangunan terjauh ke pusat kecamatan adalah 12,74 km terdapat di Kecamatan Pegandon, sedangkan Jarak bangunan terdekat ke pusat Kecamatan adalah 3,41 km terdapat di Kecamatan Kendal. Berdasarkan hasil tersebut didapat klasifikasi Jarak bangunan ke pusat Kecamatan. Kecamatan dengan Jarak bangunan terjauh ke pusat kecamatan mengindikasikan tingkat Compact City yang semakin rendah, sedangkan kecamatan dengan Jarak bangunan ke pusat Kecamatan terdekat mengindikasikan tingkat Compact City yang semakin tinggi.

Tabel 11. Jarak Bangunan Ke Pusat Kota Setiap Kecamatan Di Wilayah Perkotaan Kendal Tahun 2017 (Hasil Analisis,2018)

\begin{tabular}{|llcc} 
No & Kecamatan & $\begin{array}{c}\text { Luas } \\
\text { Wilayah } \\
(\mathrm{Ha})\end{array}$ & $\begin{array}{c}\text { Jarak Bangunan Terjauh Ke } \\
\text { Pusat Kota (Km) }\end{array}$ \\
\hline 1 & Kaliwungu & 4773 & 10,14 \\
\hline 2 & Brangsong & 3454 & 10,23 \\
\hline 3 & Pegandon & 3112 & 12,74 \\
\hline 4 & Ngampel & 3388 & 10,91 \\
\hline 5 & Patebon & 4430 & 7,40 \\
6 & Kota Kendal & 2749 & 3,41 \\
\hline
\end{tabular}

\subsection{Keterkaitan Jaringan Jalan dan Transportasi Wilayah Perkotaan Kendal}

\subsubsection{Perbandingan panjang trayek angkutan umum terhadap panjang jalan}

Analisis perbandingan panjang trayek angkutan umum terhadap panjang jalan pada enam kecamatan yang berada di Wilayah Perkotaan Kendal, dilakukan dengan menggunakan data Panjang trayek angkutan umum tahun 2017 dibagi dengan panjang jalan tahun 2017. Berikut adalah analisis perbandingan panjang trayek angkutan umum terhadap panjang jalan pada Tabel 12.

Tabel 12. Perbandingan Panjang Trayek Dan Panjang Jalan Setiap Kecamatan Di Wilayah Perkotaan Kendal Pada Tahun 2017 ( Hasil Analisis,2018)

\begin{tabular}{|llccc|} 
No & Kecamatan & $\begin{array}{c}\text { Panjang } \\
\text { Trayek } \\
\text { (M) }\end{array}$ & $\begin{array}{c}\text { Panjang } \\
\text { Jalan(M) }\end{array}$ & $\begin{array}{c}\text { Perbandingan } \\
\text { Panjang Trayek } \\
\text { dan Panjang } \\
\text { Jalan }\end{array}$ \\
\hline 1 & Kaliwungu & 3,880 & 89,985 & 0,04 \\
\hline 2 & Brangsong & 2,660 & 85,939 & 0,03 \\
\hline 3 & Pegandon & 10,200 & 96,413 & 0,11 \\
\hline 4 & Ngampel & 3,890 & 63,637 & 0,06 \\
\hline
\end{tabular}




\begin{tabular}{|c|c|c|c|c|}
\hline No & Kecamatan & $\begin{array}{l}\text { Panjang } \\
\text { Trayek } \\
\text { (M) }\end{array}$ & $\begin{array}{c}\text { Panjang } \\
\text { Jalan (M) }\end{array}$ & $\begin{array}{c}\text { Perbandingan } \\
\text { Panjang Trayek } \\
\text { dan Panjang } \\
\text { Jalan }\end{array}$ \\
\hline 5 & Patebon & 5,270 & 156,713 & 0,03 \\
\hline 6 & Kota Kendal & 6,130 & 47,506 & 0,13 \\
\hline
\end{tabular}

Berdasarkan analisis perbandingan panjang trayek angkutan umum terhadap panjang jalan pada Tabel 12. dapat diketahui bahwa perbandingan panjang trayek angkutan umum terhadap panjang jalan terendah adalah 0,03 terdapat di Kecamatan Patebon dan Kecamatan Brangsong, sedangkan perbandingan panjang trayek angkutan umum terhadap panjang jalan tertinggi adalah 0,13 terdapat di Kecamatan Kendal. Berdasarkan hasil tersebut didapat klasifikasi perbandingan panjang trayek angkutan umum terhadap panjang jalan. Kecamatan dengan perbandingan panjang trayek angkutan umum terhadap panjang jalan terendah mengindikasikan tingkat Compact City yang semakin rendah, sedangkan kecamatan dengan perbandingan panjang trayek angkutan umum terhadap panjang jalan tertinggi mengindikasikan tingkat Compact City yang semakin tinggi.

\subsubsection{Kepadatan Jaringan Jalan Wilayah Perkotaan Kendal}

Analisis kepadatan jaringan jalan pada enam kecamatan yang berada di Wilayah Perkotaan Kendal, dilakukan dengan menggunakan data panjang jalan tahun 2017 dibagi dengan luas wilayah. Berikut adalah analisis kepadatan jaringan jalan pada Tabel 13. Berdasarkan analisis kepadatan jaringan jalan pada Tabel 13. dapat diketahui bahwa kepadatan jaringan jalan terendah adalah o,017 terdapat di Kecamatan Kendal, sedangkan kepadatan jaringan jalan tertinggi adalah 0,035 terdapat di Kecamatan Patebon. Berdasarkan hasil tersebut didapat klasifikasi kepadatan jaringan jalan. Kecamatan dengan kepadatan jaringan jalan terendah mengindikasikan tingkat Compact City yang semakin rendah, sedangkan kecamatan dengan kepadatan jaringan jalan tertinggi mengindikasikan tingkat Compact City yang semakin tinggi.

Tabel 13. Kepadatan Jaringan Jalan Setiap Kecamatan Di Wilayah Perkotaan Kendal Pada Tahun 2017 ( Hasil Analisis,2018)

\begin{tabular}{|c|c|c|c|c|}
\hline No & Kecamatan & $\begin{array}{l}\text { Panjang } \\
\text { Jalan (M) }\end{array}$ & $\begin{array}{l}\text { Luas } \\
\text { Wilayah } \\
\text { (Ha) }\end{array}$ & $\begin{array}{l}\text { Kepadatan } \\
\text { Jaringan Jalan } \\
(\mathrm{M} / \mathrm{Ha})\end{array}$ \\
\hline 1 & Kaliwungu & 89,985 & 4773 & 0,019 \\
\hline 2 & Brangsong & 85,939 & 3454 & 0,025 \\
\hline 3 & Pegandon & 96,413 & 3112 & 0,031 \\
\hline 4 & Ngampel & 63,637 & 3388 & 0,019 \\
\hline 5 & Patebon & 156,713 & 4430 & 0,035 \\
\hline 6 & Kota Kendal & 47,506 & 2749 & 0,017 \\
\hline
\end{tabular}

\subsection{Urban Compactness di Wilayah Perkotaan Kendal}

Pengukuran tingkat Urban Compactness Wilayah Perkotaan Kendal ini bertujuan untuk mengklasifikasikan tingkat pengukuran Urban Compactness dari Kecamatan- Kecamatan Perkotaan yang ada di Kabupaten Kendal kedalam tiga tingkatan atau kelompok, sehingga dapat diketahui kecamatan yang berada pada tingkatan Compact City tinggi, tingkatan Compact City sedang, dan tingkatan Compact City rendah. Kemudian dalam pengukuran Urban Compactness di wilayah perkotaan Kendal tahun 2017, perlu dilakukan skoring terhadap variabel-variabel Urban Compactness di Wilayah Perkotaan Kendal yang telah diklasifikasikan kedalam 3 tingkatan tersebut. Untuk lebih jelasnya berikut Tabel 14. mengenai nilai skoring variabel pengukuruan Urban Compactness Wilayah Perkotaan Kendal. 
Tabel 14. Hasil Urban Compactness Di Wilayah Perkotaan Kendal Pada Tahun 2017 ( Hasil Analisis,2018)

\begin{tabular}{|clcc} 
No & $\begin{array}{c}\text { Kecamatan Kecamatan } \\
\text { di Wilayah Perkotaan } \\
\text { Kendal }\end{array}$ & $\begin{array}{c}\text { Jumlah Skor } \\
\text { Total Urban } \\
\text { Compactness }\end{array}$ & $\begin{array}{c}\text { Tipologi } \\
\text { Urban } \\
\text { Compactness }\end{array}$ \\
\hline 1 & Kaliwungu & 20 & rendah \\
\hline 2 & Brangsong & 19 & rendah \\
\hline 3 & Pegandon & 24 & sedang \\
\hline 4 & Ngampel & 19 & rendah \\
\hline 5 & Patebon & 19 & rendah \\
\hline 6 & Kendal & 27 & tinggi \\
\hline
\end{tabular}

\section{KESIMPULAN}

Analisis tingkat Urban Compactness di Wilayah Perkotaan Kendal dengan sasaran kepadatan, fungsi campuran, aksesibilitas kota dan Keterkaitan jaringan Jalan dan transportasi dengan menggunakan metode skoring dari variabel tersebut yang telah di jelaskan di atas. Variabel di atas dipilih karena sebagai karakteristik dalam pengukuran suatu kota yang di katakan kompak di dalam pengukuran Urban Compactness di Wilayah Perkotaan Kendal. Oleh karena itu, dari hasil analisis dinilai dan dihitung tingkat Urban Compactness di Wilayah Perkotaan Kendal terdiri dari 3 tingakatan yaitu tingakatan 1 (tingkat Urban Compactness rendah), tingakatan 2 (tingkat Urban Compactness sedang), dan tingakatan 3 (tingkat Urban Compactness tinggi). Berdasarkan hasil penilaian dan penelitian dapat dilihat dan disimpulkan bahwa nilai dari 6 Kecamatan yang ada di Perkotaan Kendal dengan tingkat Urban Compactness paling tinggi dimiliki oleh Kecamatan Kendal, kemudian skor Urban Compactness sedang dengan pengukuran variabel Urban Compactness dimiliki oleh Kecamatan Pegandon, sementara itu empat kecamatan terbawah dengan skor Urban Compactness paling rendah dengan pengukuran variabel Urban Compactness diisi oleh Kecamatan Kaliwungu, Kecamatan Brangsong, Kecamatan Patebon dan Kecamatan Ngampel. Dari hasil akhir tersebut dapat dikatakan bahwa kawasan yang paling kompak di Perkotaan Kendal yaitu Kecamatan Kendal kemudian kawasan yang paling tidak kompak yaitu Kecamatan Kaliwungu, Kecamatan Brangsong, Kecamatan Patebon dan Kecamatan Ngampel.

\section{PERNYATAAN RESMI}

Terima kasih saya ucapkan kepada Bapak dan Ibu Dosen Pengajar terkhususnya Dosen pembimbing dan seluruh staf pada Program Magister Pembangunan Wilayah dan Kota Universitas Diponegoro, serta kedua orang tua dan keluarga besar yang telah membiayai kegiatan penelitian ini hingga selesai.

\section{REFERENSI}

Apriani, vina. Indah dan manaf. Asnawi. (2015).”tipologi tingkat urban sprawl di Kota Semarang bagian selatan." jurnal teknik pwk volume 4 nomor 32015 hal. 405-416

Burton, E. (2000). "The Compact City: Just or Just Compact? A Preliminary Analysis." Urban Studies, Vol. 37, No. 11, p.1969- 2001.

Burton, Elizabeth. 2001. The Compact City and Social Justice, Housing Studies Association Spring Conference, University of New York, New York

Harahap, F. R. (2013). Dampak Urbanisasi bagi Perkembangan Kota di Indonesia.

Istanabi . Tendra . (2015). "Hubungan Urban Compactness dengan pola pergerakan penduduk kawasan Kota Surakarta.” Program Studi Perencanaan Wilayah dan Kota Fakultas Teknik UNS, Surakarta

Kusumantoro, I. P. (2007). Menggagas Bentuk Ruang Kota Alternatif: Upaya Mereduksi Intensitas Pergerakan Lalu Lintas Kota. Online. Vol. 18, No. 3 
Khaerunnisa. syifa. hapsari. (2016). "hubungan Urban Compactness dengan happiness index pada segmen ruang di kawasan perkotaan yogyakarta." program studi departemen arsitektur dan perencanaan fakultas teknik universitas gadjah. Yogyakarta.

Roychansyah, M. S. (2012). Pembangunan Infrastruktur Hijau Berorientasi Kampung (KOGID): Karakteristik, Model Aplikasi, dan Strategi Implementasi Atribut Kota Kompak di Permukiman Kampung Kota. Tahun ke-2. Yogyakarta. LPPM UGM.

Wicaksono, Agus Dwi. (2013). "Perumusan Konsep Peningktan Efektifitas Urban Compactness di Kota Surabaya". Desertasi Program Studi Perencanaan Wilayah dan Kota Institut Teknologi Sepuluh November Surabaya.

Xie, Yongqing. (2010). "Urban Compaction and Its Impact on Urban Development in China A Chase Study of Beijing". University Of Hongkong. 